\title{
PENGEMBANGAN MODUL PEMBELAJARAN KIMIA PADA MATERI SISTEM PERIODIK UNSUR BERBASIS KEARIFAN LOKAL PAPUA PESERTA DIDIK KELAS X SMA NEGERI 4 JAYAPURA
}

\author{
Subiyanto $^{1)}$ dan Tiurlina Siregar ${ }^{2)}$ \\ ${ }^{1)}$ SMA Negeri 4 Jayapura \\ ${ }^{2)}$ Program studi Magister Pendidikan IPA UNCEN
}

\begin{abstract}
.
This research is a research and development with the aim of knowing how to develop chemistry learning modules in the material of periodic system elements based on Papuan local wisdom students of class X SMA 4 Jayapura. The number of samples in this study 41 students of class X MIPA-4 SMA Negeri 4 Jayapura with representative descriptive data analysis techniques to determine the feasibility of the module. The results showed that: (1) Development of modules with stages of information gathering, planning, development, validation and testing; (2) Feasibility of the learning module compiled, based on the validation of the material validator obtained an average of $91.3 \%$ with a very feasible category, the validation of the media validator obtained a mean of $94.75 \%$ with a very feasible category while the results of the teacher response $100 \%$ strongly agree with the module learners' learning and responses of students with an average of $84.2 \%$ with interesting categories (3) This learning module is very useful for students, teachers, schools and government, (4) There is an increase in learning outcomes of class X students by using chemical modules material of periodic system elements based on local wisdom with $n$-Gain $R P P-1$ value of $0.59, R P P-2$ of 0.60 and RPP-3 of 0.67 with an average $n$-Gain value of 0.62 medium category, (5) the advantages of learning modules based on Papuan local wisdom are the first module based on local wisdom, easy to understand, contextual Papuans, language is easy to understand and improve learning achievement chemistry.
\end{abstract}

Keywords: Development of learning modules, local Papuan wisdom, elemental periodic system

\section{PENDAHULUAN}

Pasal 31 ayat (3) Undang-Undang

Dasar Negara Republik Indonesia Tahun 1945 mengamanatkan bahwa pemerintah mengusahakan dan menyelenggarakan satu sistem pendidikan nasional, yang meningkatkan keimanan dan ketakwaan serta akhlak mulia dalam rangka mencerdaskan kehidupan bangsa, yang diatur dengan undang-undang. Pasal 32 ayat (1) menyatakan bahwa negara memajukan kebudayaan nasional di tengah peradaban dunia dengan menjamin kebebasan masyarakat dalam memelihara dan mengembangkan nilai $\quad-$ nilai budayanya. Artinya semua pemerintah daerah dan semua stakeholder harus mengambil peran dalam upaya kemajuan kebudayaan daerah berdasarkan kearifan lokalnya. Dalam dunia pendidikan misalnya dalam proses pembelajarannya.

Proses pembelajaran pada satuan pendidikan diselenggarakan secara interaktif, inspiratif, menyenangkan, 
menantang, memotivasi peserta didik untuk berpartisipasi aktif, serta memberikan ruang yang cukup bagi prakarsa, kreativitas, dan kemandirian sesuai dengan bakat, minat, dan perkembangan fisik serta psikologis peserta didik. Untuk itu setiap satuan pendidikan melakukan perencanaan pembelajaran, pelaksanaan proses pembelajaran serta penilaian proses pembelajaran untuk meningkatkan efisiensi dan efektivitas ketercapaian kompetensi lulusan (Lampiran Permendikbud Nomor 22 tahun 2016).

Fungsi dan peranan pendidikan di dalam kehidupan suatu bangsa tidak bisa terlepas dari kehidupan politik, ekonomi, hukum, dan kebudayaan. Perluasan otonomi daerah menyebabkan perubahan kebijakan di dalam dunia pendidikan, dimana daerah memiliki porsi yang lebih besar dalam menentukan kebijakan pendidikan. Sehingga daerah dan sekolah diberi kewenangan untuk menentukan sistem yang akan digunakan dalam melaksanakan proses pembelajaran, dan strategi pembelajaran. Hal ini merupakan peluang bagi daerah untuk mengembangkan kearifan lokal dalam kaitannya dengan pembelajaran.

Kearifan lokal (local wisdom) dalam kamus terdiri dari dua kata: kearifan (wisdom) dan lokal (local). Dalam Kamus Inggris Indonesia John M. Echols dan Hassan Syadily (2014), local berarti setempat, $\quad$ sedangkan wisdom (kearifan) sama dengan kebijaksanaan. Secara umum maka local wisdom (kearifan lokal) adalah gagasan-gagasan setempat (local) yang bersifat bijaksana, penuh kearifan, bernilai baik, yang tertanam dan diikuti oleh anggota masyarakatnya. Dalam disiplin antropologi dikenal istilah local genius. Secara konseptual, kearifan lokal dan keunggulan lokal merupakan kebijaksanaan manusia yang bersandar pada filosofi nilai-nilai, etika, cara-cara dan perilaku yang melembaga secara tradisional. Menurut Antariksa (2009), kearifan lokal merupakan unsur bagian dari tradisi-budaya masyarakat suatu bangsa, yang muncul menjadi bagian-bagian yang ditempatkan pada tatanan fisik bangunan (arsitektur) dan kawasan (perkotaan) dalam geografi kenusantaraan sebuah bangsa. Kearifan lokal merupakan langkah penerapan dari tradisi yang diterjemahkan dalam artefak fisik. Hal terpenting dari kearifan lokal adalah proses sebelum implementasi tradisi pada artefak fisik, yaitu nilai-nilai dari alam untuk mengajarkan tentang bagaimana 'membaca' potensi alam dan menuliskannya kembali sebagai tradisi yang diterima secara universal oleh masyarakat, khususnya dalam berarsitektur misalnya kearifan lokal di Provinsi Papua.

Papua merupakan propinsi yang sebagian besar penduduknya tinggal di 
daerah pedesaan, yang hidup secara berkelompok - kelompok dan memiliki hutan yang luas. Kondisi inilah yang menyebabkan Papua juga kaya akan budaya seperti tarian, lagu daerah, ukir ukiran, batik, bahasa, flora maupun fauna. Studi tentang kearifan lokal pada masyarakat Papua mungkin sudah banyak dilakukan, tetapi pemanfaatan kearifan lokal sebagai sumber belajar di sekolah dapat diakui belum mendapat perhatian pendidik, praktisi pendidikan, dan pemerintah daerah Papua.

Visi kota Jayapura "Terwujudnya Kota Jayapura yang Beriman, Bersatu, Sejahtera, Mandiri, dan Modern berbasis kearifan lokal“. Implementasikan visi kota Jayapura sebagai ibu kota provinsi Papua dapat diterapkan/ dilaksanakan ke dalam proses pembelajaran di sekolah melalui mata pelajaran yang terintegrasi kearifan lokal. Kearifan lokal akan lebih bermakna jika mampu diajarkan secara sistematis kepada peserta didik di sekolah, sehingga peserta didik akan merasa tidak asing karena berada pada lingkungannya sendiri. Peserta didik perlu dilibatkan secara fisik dan emosional dalam proses pembelajaran kearifan lokal dengan menggunakan segala sumber yang tersedia baik di sekolah maupun di lingkungan luar sekolah. Pembelajaran kearifan lokal dengan sumber belajar yang bervariasi dapat diimplementasikan seperti modul yang berbasis kearifan lokal sehingga dapat meningkatkan pengetahuan peserta didik dalam melaksanakan pembelajaran pada materi yang diajarkan sesuai lingkungan belajar peserta didik.

Menurut Andi Prastowo (2012), modul merupakan bahan ajar yang disusun secara sistematis dengan bahasa yang mudah dipahami oleh peserta didik, sesuai usia dan tingkat pengetahuan peserta didik agar dapat belajar secara mandiri dengan bimbingan minimal dari pendidik. Salah satu karakteristik modul menurut Lestari (2013) modul hendaknya bersahabat dengan pemakainya. Artinya setiap instruksi dan paparan informasi yang tampil bersifat membantu dan bersahabat dengan pemakainya, termasuk kemudahan pemakai dalam merespon, mengakses sesuai dengan keinginan. Penggunaan bahasa yang sederhana, mudah dimengerti serta menggunakan istilah yang umum digunakan merupakan salah satu bentuk user friendly, hal inilah yang menjadi dasar mengapa perlu mengembangkan modul berbasis kearifan lokal setempat.

Di lingkungan SMA Negeri 4 Jayapura pengembangan modul berbasis kearifan lokal pada mata pelajaran belum ada, kenyataan menunjukkan bahwa banyak dijumpai para peserta didik sebagai generasi muda tidak mengenal lagi kearifan lokal Papua seperti: bahasa, ritual adat, tarian lokal, seni ukir tradisional, makanan 
tradisional, flora, fauna dan para pejuang Papua, karena peserta didik lebih memilih kearifan lokal dari luar Papua sebagai akibat dari maraknya peserta didik menggunakan media sosial, ataupun media televisi yang dianggap lebih menarik. Kondisi seperti ini akan berdampak pada terkikisnya kearifan lokal oleh budaya atau kearifan dari luar.

Kearifan lokal dapat diintegrasikan ke dalam pelbagai mata pelajaran seperti sosiologi, antropologi, kimia, muatan lokal, seni budaya, bahasa Indonesia ataupun pelajaran yang lainnya. Pelajaran kimia sebagai bagian dari Ilmu Pengetahuan Alam diperoleh dan dikembangkan berdasarkan percobaan untuk mencari jawaban atas pertanyaan apa, mengapa, dan bagaimana tentang gejala-gejala alam khususnya yang berkaitan dengan komposisi, struktur, sifat, transformasi, dinamika dan energetika zat. Dalam rangka penguasaan kecakapan abad 21 maka pembelajaran kimia di SMA dipandang bukan hanya untuk pengalihan pengetahuan dan keterampilan (transfer of knowledge and skills) saja kepada peserta didik, tetapi juga untuk membangun kemampuan berpikir tingkat tinggi (analitis, sintesis, kritis, kreatif, dan inovatif) melalui pengalaman kerja ilmiah. Selain itu pembelajaran kimia dapat digunakan sebagai wahana untuk memahami alam, untuk membangun sikap dan nilai, serta untuk meningkatkan keimanan terhadap Tuhan Yang Maha Esa (silabus mata pelajaran kimia:2016). Integrasi mata pelajaran kimia untuk kearifan lokal Papua dapat dicantumkan dalam materi tentang sistem periodik unsur, dimana dalam pembelajaran kimia pada materi sistem periodik unsur. Penggambaran pada masing - masing unsur dapat berupa flora, fauna, seni budaya, batik, makanan khas, pahlawan dan lainnya yang ada di Papua untuk menghubungkan materi pelajaran dengan kondisi nyata agar terciptanya proses pembelajaran yang bermakna. Selain meningkatkan prestasi belajar peserta didik pada pelajaran kimia juga diharapkan untuk penguatan pendidikan karakter berbasis keunggulan lokal, mengenalkan dan melestarikan kearifan lokal Papua kepada peserta didik yang ada di SMA Negeri 4 Jayapura pada umumnya dan seluruh peserta didik di kota Jayapura serta Provinsi Papua pada umumnya.

Berdasarkan paparan tersebut maka penulis telah melakukan suatu penelitian. Judul penelitian "Pengembangan Modul Pembelajaran Kimia Pada Materi Sistem Periodik Unsur Berbasis Kearifan Lokal Papua Peserta Didik Kelas X SMA Negeri 4 Jayapura".

\section{METODOLOGI PENELITIAN}

Dalam Penelitian ini merupakan penelitian pengembangan ( $R \quad \& \quad D)$, peneliti 
mengambil materi sistem periodik unsur kelas X Peminatan Matematika dan Ilmu pengetahuan Alam (MIPA) dengan pendekatan pengembangan menggunakan kelas uji coba skala kecil dan kelas ujicoba skala luas. Desain eksperimen yang digunakan pada uji lapangan maupun pada uji coba satu-satu, uji coba kelompok kecil dan uji coba kelas adalah One-Group Pretest-Posttest Design, yang terdiri dari satu kelompok eksperimen tanpa ada kontrol, (Sugiyono, 2015 ) ditunjukkan tabel 1 sebagai berikut :

Tabel 1 Model Penelitian dan pengembangan

\begin{tabular}{|l|l|l|l|}
\hline Uji coba & $\begin{array}{l}\text { Perla } \\
\text { kuan }\end{array}$ & $\begin{array}{l}\text { Pre } \\
\text { test }\end{array}$ & $\begin{array}{l}\text { Post } \\
\text { test }\end{array}$ \\
\hline $\begin{array}{l}\text { Skala Kecil/ } \\
\text { terbatas }\end{array}$ & - & - & - \\
\hline $\begin{array}{l}\text { Skala Besar/ } \\
\text { luas }\end{array}$ & $\mathrm{X}$ & $\mathrm{O}_{1}$ & $\mathrm{O}_{2}$ \\
\hline
\end{tabular}

Keterangan:

$\mathrm{X}=$ pembelajaran dengan modul kimia berbasis kearifan lokal Papua $\mathrm{O}_{1}=$ pretest pada kelas ujicoba skala besar/ luas

$\mathrm{O}_{2} \quad=$ posttest pada kelas ujicoba skala besar/ luas

Penelitian ini dilaksanakan di SMA Negeri 4 Jayapura kelas X Peminatan Matematika dan Ilmu Pengetahuan Alam
Dengan langkah-langkah sebagai berikut :

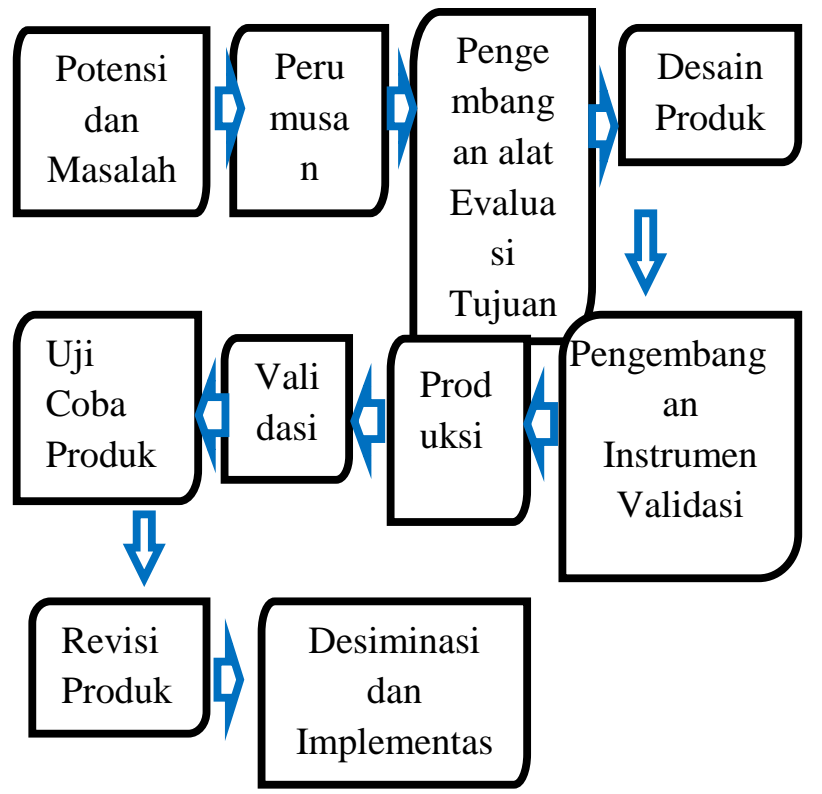

Ujicoba Produk

Uji coba produk dilaksanakan pada peserta didik SMA Negeri 4 Jayapura kelas $\mathrm{X}$ peminatan Matematika dan Ilmu Pengetahuan Alam (MIPA)

\section{Desain Uji Coba}

Produk yang dihasilkan berupa modul perlu dilakukan pengujian agar dapat mengetahui kualitas dan kelayakannya. Uji produk merupakan bagian rangkaian dari tahap validasi dan evaluasi.

\section{Subjek Uji Coba}

Populasi dalam penelitian ini adalah peserta didik kelas $\mathrm{X}$ peminatan matematika dan ilmu pengetahuan alam (MIPA) sebanyak 8 kelas tahun pelajaran 2017/2018. Subyek dalam penelitian ini meliputi pakar/ahli, pendidik mata pelajaran kimia, dan satu kelas peminatan MIPA peserta didik di SMA Negeri 4 Jayapura. 


\section{Variabel Penelitian}

Dalam penelitian ini menggunakan variabel bebas dan variabel terikat.

1. Variabel bebas

Variabel bebas dalam penelitian ini adalah pembelajaran mandiri dengan menggunakan modul kimia pada materi kimia unsur berbasis kearifan lokal Papua.

2. Variabel terikat

Variabel terikat pada penelitian ini adalah hasil belajar peserta didik kelas $\mathrm{X}$ dengan menggunakan modul pembelajaran kimia unsur berbasis kearifan lokal Papua.

\section{Jenis Data}

Terdapat dua jenis data dalam penelitian pengembangan ini yaitu data primer dan data sekunder. Data primer diperoleh dari hasil wawancara terhadap guru kimia di sekolah serta saran, kritik dan tanggapan dari para validator, data tersebut berupa skor penilaian dari aspek kelayakan isi modul, bahasa, dan penyajian. Data sekunder diperoleh dari nilai post test dan penyebaran angket respon peserta didik. Setelah kedua jenis data terkumpul, kemudian akan dianalisis.

\section{Instrumen Pengumpulan Data}

Instrumen pengumpulan data pada penelitian ini berupa instrumen non tes (kuesioner/angket), instrumen tes, diskusi dan wawancara.

\section{Teknik analisa data}

Hasil nilai pretest dan posttest sebagai data kuantitatif dianalisis dengan uji n-Gain ternormalisasi yang dirumuskan sebagai berikut :

$(\mathrm{g})=\frac{(S f)-(S i)}{\text { Smaks }-S i}$ Elice , 2012

Dimana :

(g) = gain ternormalisasi

(Sf) = Nilai posttest

(Si) $\quad=$ Nilai pretest

Smaks = Nilai maksimum

$\mathrm{Si} \quad=$ Nilai Minimum

\section{HASIL DAN PEMBAHASAN}

1. Cara pengembangan isi modul pembelajaran kimia pada materi Sistem Periodik Unsur berbasis kearifan lokal Papua peserta didik

\section{kelas X SMA Negeri 4 Jayapura.}

Modul pembelajaran kimia pada materi sistem periodik unsur berbasis kearifan lokal Papua kelas X terdiri dari 3 (tiga) komponen yaitu sebagai berikut :

1. Bagian pendahuluan yang terdiri dari halaman judul, latar belakang, tujuan, peta kompetensi, ruang lingkup dan cara penggunaan modul.

2. Bagian isi yang terdiri dari tujuan pembelajaran, indikator pencapaian kompetensi, uraian materi, aktivitas pembejaran tes sumatif dan kunci jawaban.

3. Bagian penutup yang terdiri dari 
glosarium dan daftar pustaka.

Tahapan dalam pengembagan modul pembelajaran kimia pada materi sistem periodik unsur berbasis kearifan lokal adalah sebagai berikut a) pengumpulan informasi;b) perencanaan;c) pengembangan produk;d) validasi; e ) uji coba.

\section{Kelayakan modul pembelajaran}

kimia pada materi Sistem Periodik

\section{Unsur berbasis kearifan lokal Papua}

Kelayakan modul pembelajaran sistem periodik unsur berbasis kearifan lokal Papua ini dapat dilihat dari validasi validator materi, validator media, respon guru mata pelajaran dan peserta didik.

Validasi Materi (gambar 1) :

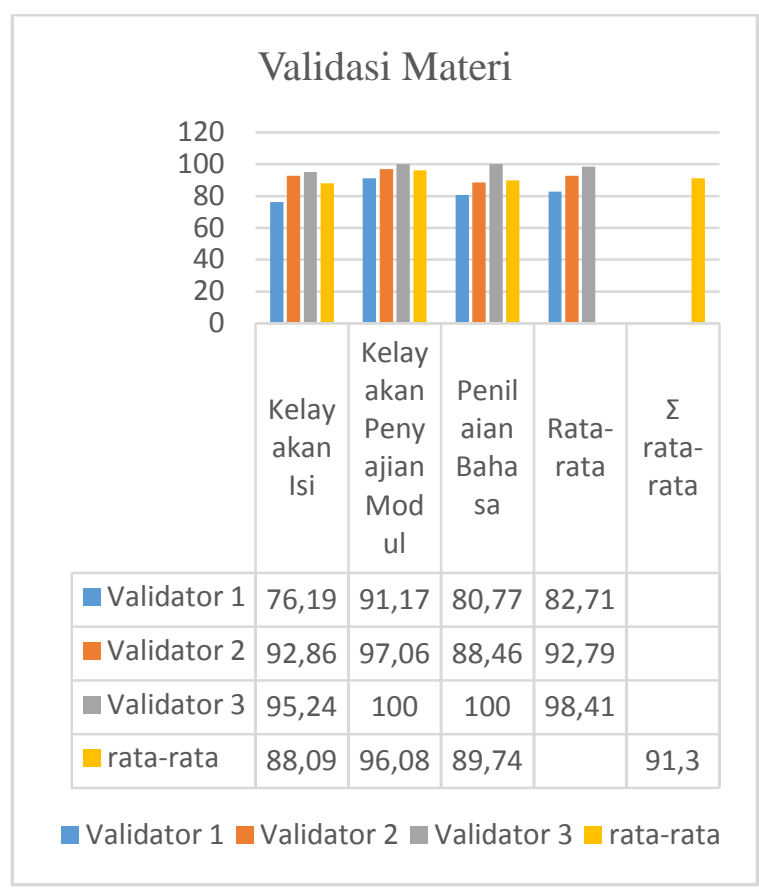

Berdasarkan gambar 1 hasil validasi dari validator materi diperoleh rerata validasi adalah 91,3\% dengan kategori modul sangat baik.
Validasi Media (gambar 2) :

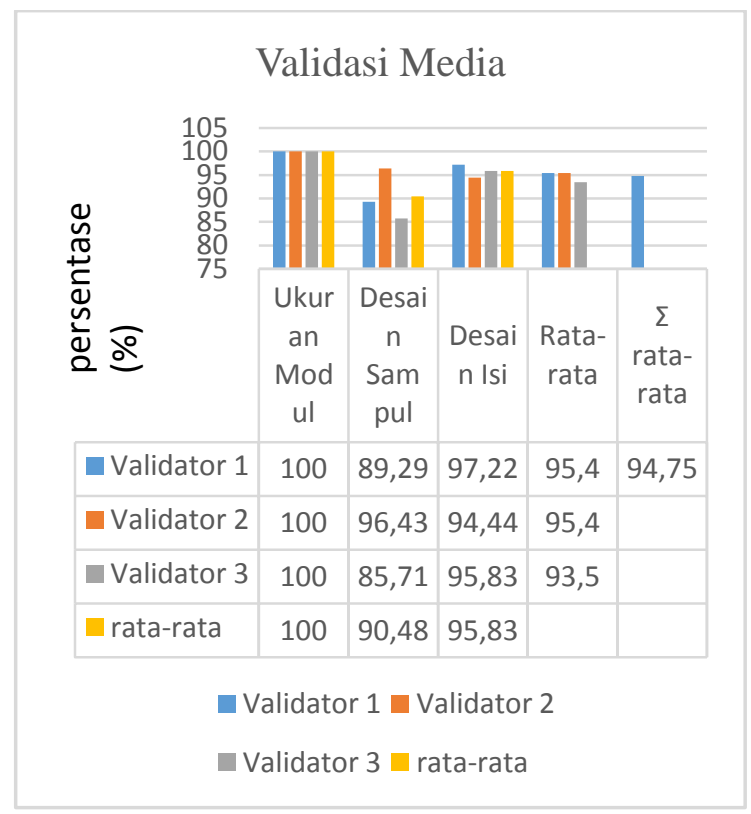

Berdasarkan gambar 2 hasil validasi validator media diperoleh rerata sebesar 94,75\% dengan kategori sangat baik. Yang berarti bahwa modul ditnjau dari segi ukuran sudah baik sesuai dengan standar yaitu ukuran A4, desain cover sudah mencerminkan kearifan lokal Papua, dan desain isi menggambarkan kearifan lokal Papua yang dituangkan ke dalam lambanglambang unsur kimia dengan gambargambar khas Papua. berdasarkan hasil validasi tersebut maka modul sangat layak digunakan dalam pembelajaran.

Tanggapan Guru (gambar 3) :

$$
\begin{aligned}
& \text { Tanggapan Guru } \\
& 0 \quad 0 \\
& 100 \\
& 100 \\
& \text { - Guru } 1 \text { guru } 2
\end{aligned}
$$

Berdasarkan gambar 3 angket yang diisi guru mata pelajaran kimia sebanyak 2 
(dua) guru yang mengampu kelas $\mathrm{X}$ peminatan matematika dan ilmu pengetahuan alam, keduanya memberikan respon $100 \%$ sangat setuju dengan adanya modul pembelajaran kimia pada materi sistem periodik unsur berbasis kearifan lokal Papua dapat menciptakan pembelajaran yang menyenangkan dan dapat mengenalkan kaearifan lokal Papua Respon Peserta Didik ( gambar 4)

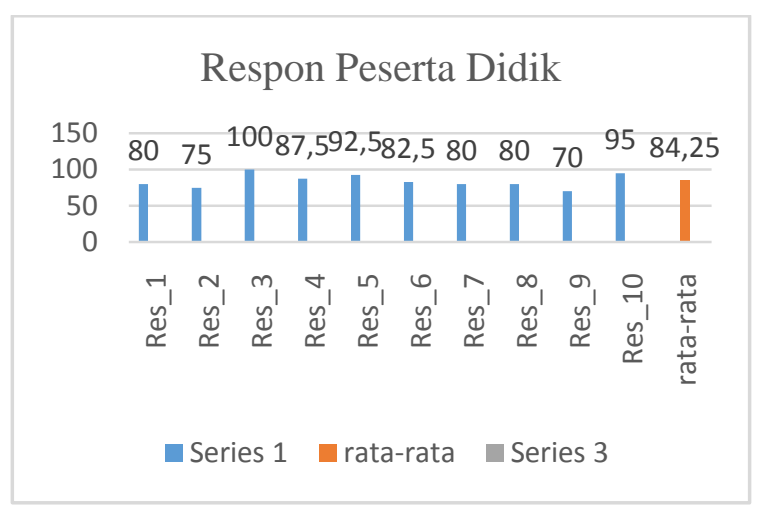

Hasil yang didapat dari pengisian angket respon peserta didik (gambar 4) adalah dengan rerata persentase $84,25 \%$ dengan kategori sangat baik, sehingga modul pembelajaran kimia pada materi sistem periodik unsur berbasis kearifan lokal Papua layak digunakan dalam proses pembelajaran.

Hasil uji reliabilitas menggunakan SPSS 21 nilai alpha cronbach's adalah 0,846 dan nilai pada kolom cronbach's alpha if item deleted pada masing-masing pertanyaan semua $>0,60$ sehingga semua pertanyaan reliabel.

1. Uji coba skala luas

Ujicoba skala luas dilaksanakan di
SMA Negeri 4 Jayapura kelas X MIPA 4, Ujicoba skala luas dilakukan dengan cara melakukan proses pembelajaran dengan media modul yang telah disusun sebanyak 3 (tiga) kali pertemuan, setiap pertemuan diawali dengan pretest dan diakhri dengan post test. Hasil ujicoba skala luas berupa nilai pretest dan post test di analisis dengan n-Gain.

\section{Manfaat modul pembelajaran kimia pada materi Sistem Periodik Unsur \\ berbasis kearifan lokal Papua}

Manfaat teoritis adalah dapat memberikan sumbangsih pada ilmu pengetahuan khususnya mata pelajaran kimia agar dapat tercipta pembelajaran yang mampu mendorong peserta didik untuk berfikir kritis, kreatif, kolaboratif dan komunikatif dan dapat meningkatkan motivasi belajar peserta didik serta mengenal kearifan lokal Papua, sedangkan manfaat praktis adalah :

a. Peserta didik

1. Memiliki bahan ajar mandiri

2. Sebagai alat evaluasi

Modul pembejaran kimia ini dilengkapi dengan latihan soal dan tes sumatif sehingga dapat digunakan untuk alat evaluasi mandiri.

3. Sebagai bahan rujukan

4. Memudahkan peserta didik dalam belajar 
b. Pendidik/guru

Modul pembelajaran kimia pada materi sistem periodik unsur barbasis kaearifan lokal Papua dapat memotivasi pendidik/guru untuk berinovasi dalam menciptakan pembelajaran yang menarik berbasis kearifan lokal Papua.

c. Satuan pendidikan/sekolah

Modul pembelajaran kimia pada materi sistem periodik unsur berbasis kearifan lokal Papua untuk pengembangan kurikulum tingkat satuan pendidikan.

d. Bagi pemerintah

Modul pembelajaran kimia pada materi sistem periodik unsur berbasis kearifan lokal Papua mendukung misi pemerintah kota Jayapura yaitu terwujudnya kota Jayapura yang beriman, bersatu, sejahtera, mandiri, dan modern berbasis kearifan lokal. Selain itu pula mendukung program pemerintah provinsi Papua dalam hal ini bidang guru dan tenaga kependidikan (GTK) untuk membuat buku berbasis kearifan lokal (kontekstual Papua).

4. Peningkatan hasil belajar kimia menggunakan modul pembelajaran sistem periodik unsur berbasis kearifan lokal Papua

Penelitian ini dilakukan sebanyak tiga kali pertemuan dengan jumlah peserta didik
41 orang. Uji n-Gain digunakan untuk melihat peningkatan hasil belajar peserta didik berdasarkan nilai pretest dan post test yang diberikan selama proses pembelajaran dengan modul.

\section{Hasil pretest dan post test}

Hasil pretest dan post test dianalisis dengan menggunakan n-Gain dengan tujuan untuk mengetahui peningkatan pemahaman atau penguasaan konsep peserta didik setelah pembelajaran dilakukan oleh guru.

Nilai Rata-rata Pre Test dan Post Test RPP 1 s/d RPP 3 (gambar 5) :

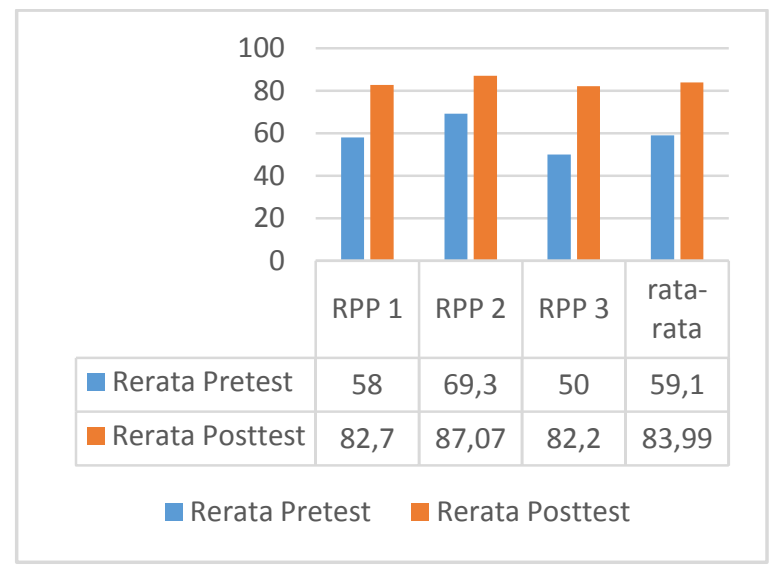

n - Gain rata-rata RPP 1 s/d RPP 3 (gambar 6) :

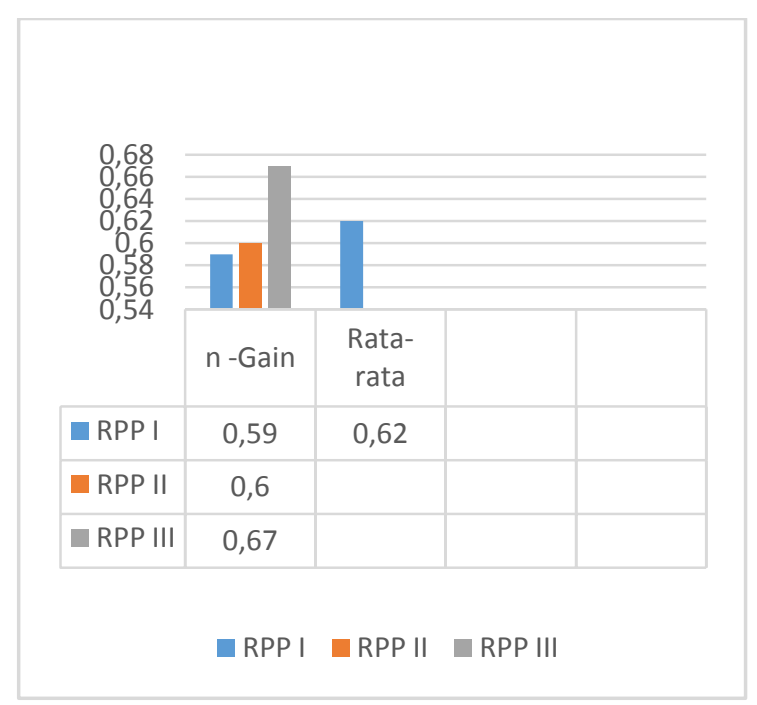


Berdasarkan Gambar 5 dan 6 hasil uji n-Gain menunjukan adanya peningkatan pada setiap pertemuan, dengan nilai $\mathrm{n}-\mathrm{Gain}$ rata-rata untuk RPP-1 adalah 0,59 dengan kategori sedang, pada RPP-2 diperoleh nGain sebesar 0,60 dengan kategori sedang, pada RPP-3 diperoleh n-Gain sebesar 0,67 dengan kategori sedang. Dari data tersebut rata-rata $\mathrm{n}$-Gain rata-rata adalah sebesar 0,62 yang termasuk dalam kategori sedang dan tingkat efektifitas cukup efektif.

\section{Kelebihan modul pembelajaran kimia pada materi Sistem Periodik Unsur berbasis kearifan lokal Papua di SMA Negeri 4 Jayapura}

Modul ini memiliki kelebihan antara lain :

a. Modul pertama di SMA Negeri 4 Jayapura yang berbasis kearifan lokal Papua.

b. Belajar dengan menggunakan modul ini lebih menarik, karena materi kimia yang berupa lambang-lambang unsur kimia dikaitkan dengan gambar-gambar seperti pahlawan Papua, nama tempat di Papua, nama tarian, rumah adat, makanan, flora, fauna, nama gunung, nama sungai yang semuanya ada di Papua (kontekstual Papua).

c. Modul ini dilengkapi dengan panduan penggunaan modul sehingga memudahkan peserta didik untuk belajar mandiri. d. Modul ini dilengkapi dengan aktivitas pembelajaran, rangkuman,latihan soal dan refleksi, sehingga lebih efektif dan efisien.

e. Penggunaan bahasa yang sederhana dalam modul ini menjadikan modul ini mudah untuk dipahami.

f. Prestasi belajar kimia akan meningkat dan pengetahuan akan Papua semakin baik dengan mengenal kearifan lokal Papua.

\section{SIMPULAN DAN SARAN}

\section{A. SIMPULAN}

Berdasarkan penelitian pengembangan dengan menganalisis data hasil penelitian yang telah dilakukan dapat disimpulkan bahwa :

1. Cara pengembangan isi modul pembelajaran kimia pada materi sistem periodik unsur berbasis kearifan lokal Papua peserta didik kelas X SMA Negeri 4 Jayapura dilakukan dengan tahapan pengumpulan informasi, perencanaan, pengembangan, validasi dan uji coba.

2. Modul pembelajaran kimia pada materi sistem periodik unsur berbasis kearifan lokal Papua layak digunakan sebagai modul pembelajaran sesuai data hasil validasi validator materi dengan rerata $91,3 \%$, validasi validator media dengan rerata $94,75 \%$, respon pendidik $100 \%$ sangat setuju dan uji terbatas $84,25 \%$. 
3. Modul pembelajaran kimia pada materi sistem periodik unsur berbasis kearifan lokal Papua kelas X memiliki manfaat bagi peserta didik, pendidik, sekolah maupun pemerintah untuk meningkatkan kualitas pendidikan berbasis kearifan lokal Papua.

4. Ada peningkatan hasil belajar kimia menggunakan modul pembelajaran sistem periodik unsur berbasis kearifan lokal Papua, RPP-1 dengan n-Gain ratarata sebesar 0,59 dengan kategori sedang, RPP-2 dengan n-Gain rata-rata sebesar 0,60 dengan kategori sedang dan RPP-3 dengan n-Gain rata-rata sebesar 0,67 dengan kategori sedang dan nilai $n$-Gain rata-rata total adalah 0,62 dengan kategori sedang.

5. Kelebihan modul pembelajaran kimia pada materi sistem periodik unsur berbasis kearifan lokal Papua di SMA Negeri 4 Jayapura adalah merupakan modul pertama yang berbasis kearifan lokal Papua, modul ini menarik karena pembelajaran kimia dikaitkan dengan kearifan lokal Papua dengan menggunakan gambar nama-nama yang ada di Papua seperti nama tempat, nama tarian, nama gunung, nama rumah adat, nama flora dan fauna, nama pahlawan dan makanan. Berdasarkan hasil angket respon peserta didik dari aspek kemenarikan dan kemudahan dalam penggunaan modul diperoleh rerata $84,25 \%$ dengan kategori menarik.

\section{B. SARAN}

Dalam penelitian pengembangan dengan produk media pembelajaran ini peneliti mempunyai saran sebagai berikut :

1. Media modul pembelajaran kimia pada materi sistem periodik unsur berbasis kearifan lokal Papua, memang telah divalidasi oleh validator materi, validator media, guru dan peserta didik, namun tidak menutup kemungkinan masih terdapat kekeliruan, sehingga revisi dari pengembangan modul pembejaran ini dapat terus dilakukan agar terwujudnya modul pembelajan yang lebih baik.

2. Media modul pembejaran berbasis kearifan lokal Papua ini belum diaplikasikan dalam semua mata pelajaran, dan dalam modul ini untuk deret lantanida dan aktinida perlu dilanjutkan dengan penelitian berikutnya.

3. Pengembangan modul ini diharapkan menjadi cikal bakal untuk para guru mata pelajaran lain menyusun modul berdasarkan kearifan lokal Papua.

4. Modul pembelajaran kimia berbasis kearifan lokal ini dapat digunakan untuk peningkatan belajar kimia dan pengetahuan akan kearifan lokal Papua. 


\section{DAFTAR PUSTAKA}

Antariksa.2009. Kearifan Lokal Dalam

Arsitektur Perkotaan Dan

Lingkungan Binaan. On line.

Elice, Deti. 2012. Pengembangan Desain

Bahan Ajar Keterampilan Aritmatika

Menggunakan Media Sempoa Untuk

Guru Sekolah Dasar. Tesis. FKIP

Unila PPSJ Teknologi Pendidikan.

Bandar Lampung

Ika Lestari. 2013. Pengembangan Bahan

Ajar Berbasis Kompetensi. Padang:

Akademia Permata.

John M. Echols dan Hassan Shadily, 2014.

Kamus Inggris - Indonesia,

Granmedia Pustaka Utama.

Permendikbud Nomor 22 , 2016. Standar

Proses, Jakarta : Kemendikbud

Prastowo, Andi , 2012. Panduan Kreatif

Membuat Bahan Ajar Inovatif.

Yogyakarta: Diva Press.

Silabus Mata pelajaran Kimia revisi tahun 2016, Jakarta : Kemendikdub

Sugiyono. 2015. Metode penelitian

Pendidikan (Pendekatan Kuantitatif,

Kualitatif dan $R$ \& D). Bandung :

Alfabeta

Undang - Undang Dasar Negara Republik

Indonesia tahun 1945 